\title{
Relationship Between Meat Quality, Carcass Characteristics, and Protein Abundance of HSP $\beta 1$, HSPA, and DJ1 in Beef Longissimus thoracis Pre-Rigor or After 14 Days' Aging
}

\author{
Reganne K. Briggs ${ }^{1}$, Rachael C. Christensen ${ }^{1,2}$, Shelby M. Quarnberg ${ }^{3}$, Jerrad F. Legako ${ }^{4}$, \\ Randall C. Raymond ${ }^{5}$, Michael D. MacNeil ${ }^{6,7}$, and Kara J. Thornton ${ }^{1 *}$ \\ ${ }^{1}$ Animal, Dairy and Veterinary Sciences, Utah State University, Logan, UT 84322, USA \\ ${ }^{2}$ North Great Plains Research Laboratory, USDA-Agricultural Research Service, Mandan, ND 58554, USA \\ ${ }^{3}$ Nutrition, Dietetics, and Food Science, Utah State University, Logan, UT 84322, USA \\ ${ }^{4}$ Animal and Food Sciences, Texas Tech University, Lubbock, TX 79409, USA \\ ${ }^{5}$ Simplot Land \& Livestock, Grand View, ID 83624, USA \\ ${ }^{6}$ Delta G, Miles City, MT 59301, USA \\ ${ }^{7}$ Department of Animal, Wildlife and Grassland Sciences, University of the Free State, Bloemfontein, 9300, South Africa \\ *Corresponding author. Email: kara.thornton@usu.edu (Kara J. Thornton)
}

\begin{abstract}
This study evaluated associations of heat shock proteins (HSP) and an oxidative stress protein, protein deglycase (DJ1), with beef quality and tenderness. Samples from the longissimus thoracis $(N=99)$ were collected pre-rigor (day 0$)$ and after 14-d aging. Warner-Bratzler shear force (WBSF), myofibrillar fragmentation index (MFI), and a trained sensory panel were used to determine meat quality. Protein abundance of DJ1 and 2 HSP-HSP $\beta 1$ and HSPA-were assessed. Regression analyses demonstrated that DJ1 abundance after $14 \mathrm{~d}$ of aging is a predictor of WBSF $(P<0.001)$, MFI $(P=0.02)$, and sensory panel tenderness $(P<0.001)$. Abundance of HSP $\beta 1$ after $14 \mathrm{~d}$ of aging is also a predictor of MFI $(P=0.03)$. Additionally, abundance of both HSP $\beta 1$ and DJ1 pre-rigor are predictors of juiciness $(P<0.05)$. Abundance of HSP $\beta 1$ pre-rigor was correlated with WBSF $(R=0.67)$, sensory panel tenderness $(R=-0.44)$, juiciness $(R=-0.30)$, and umami $(R=-0.20)$. Abundance of DJ1 pre-rigor was also correlated with WBSF $(R=0.72)$, sensory panel tenderness $(R=-0.44)$, juiciness $(R=-0.24)$, and umami $(R=-0.31)$. After 14-d aging, HSP $\beta 1$ abundance was correlated with WBSF $(R=0.66)$, sensory panel tenderness $(R=-0.34)$, juiciness $(R=-0.34)$, umami $(R=-0.33)$, and brown/ roasted $(R=-0.30)$. Abundance of DJ1 after 14-d aging was also correlated with WBSF $(R=0.68)$, sensory panel tenderness $(R=-0.41)$, juiciness $(R=-0.21)$, and umami $(R=-0.28)$. These results demonstrate that abundance of HSP $\beta 1$ and DJ1 both pre-rigor and after $14 \mathrm{~d}$ of aging are correlated with meat tenderness and end-product quality as assessed by a trained sensory panel. Regression analyses further reveal that abundance of DJ1 and HSP $\beta 1$ after $14 \mathrm{~d}$ of aging is causative in development of beef tenderness and juiciness, respectively. Taken together, these results suggest that abundance of DJ1 is a predictor of tenderness, whereas abundance of HSP $\beta 1$ is related to meat quality but cannot be used to predict tenderness.
\end{abstract}

Key words: beef, heat shock proteins, meat quality, oxidative stress, tenderness

Meat and Muscle Biology 5(1): 22, 1-14 (2021)

doi: $10.22175 / \mathrm{mmb} .11685$

Submitted 14 October 2020

Accepted 31 December 2020

\section{Introduction}

Consumers consider tenderness to be one of the most important qualities of beef and are willing to pay a premium price for a product with guaranteed tenderness (Miller et al., 2001; Koohmaraie et al., 2002; Laville et al., 2009; Lucero-Borja et al., 2014). However, despite similar production practices, beef cattle exhibit undesirable variation in the rate and extent of postmortem proteolysis leading to 
inconsistencies in tenderness. The process of tenderization occurs during the conversion of muscle to meat as a result of proteolysis of myofibrillar and associated structural proteins within the muscle (Laville et al., 2009). Proteolytic systems, such as calpains, cathepsin, caspases, and the proteasome have each been studied to some extent and are known to play a role in the postmortem tenderization process (Sentandreu et al., 2002; Koohmaraie and Geesink, 2006; Ouali et al., 2013). In addition to proteolysis, several other biological pathways-including muscular structure and contraction, heat shock proteins (HSP), apoptosis, transport, and metabolism-are each related to meat tenderness (D'Alessandro et al., 2012a; Picard et al., 2014; Baldassini et al., 2015; Picard et al., 2015; Lana and Zolla, 2016; Picard and Gagaoua, 2017).

HSP are a family of chaperone proteins that are both constitutively expressed and upregulated by cells and tissues in response to cell stressors and have a homeostatic function refolding denatured proteins and preventing protein aggregation, ultimately protecting the cell from apoptosis (Ritossa, 1962; Tissiéres et al., 1974; Pulford et al., 2008; Balan et al., 2014). HSP have been classified into several different families based on their molecular weight. Two families of HSP that have been found to play a role in meat quality are HSPA (Hsp70) and HSPB (small HSP). HSPA is constitutively expressed, upregulated in response to stress, and is adenosine triphosphate (ATP) dependent (Welch, 1992; Creagh et al., 2000). Members of the HSPB, including HSP27 (HSP $\beta 1$ ), are upregulated in response to stress and are thought to act as molecular chaperones, specifically protecting myofibrillar proteins from degradation during events in which the muscle tissue is stressed, such as postmortem conditions (Mymrikov et al., 2011; Balan et al., 2014; Lomiwes et al., 2014). Similar to HSP, the protein deglycase 1 (DJ1) is thought to be involved in cellular protection from apoptosis (Laville et al., 2009; Longo et al., 2015). To date, several studies have determined that DJ1 abundance is related to meat tenderness (Jia et al., 2009; Guillemin et al., 2011b; Picard et al., 2014; Gagaoua et al., 2015). As such, many studies have investigated the relationship between HSP, DJ1, and development of tenderness (Guillemin et al., 2011a; D'Alessandro et al., 2012b; Picard and Gagaoua, 2017; Rosa et al., 2017; Malheiros et al., 2018; Malheiros et al., 2019; Gagaoua et al., 2020; $\mathrm{Ma}$ and Kim, 2020). However, few studies have analyzed the relationship between abundance of HSP and carcass characteristics. Previous research indicates that steers with an increased yield grade have decreased expression of HSP $\beta 1$ (Keady et al., 2013). Animals that are more susceptible to stress have less desirable carcass characteristics and increased abundance of several different HSP; however, previous research has not characterized the relationship between HSP abundance and carcass characteristics (King et al., 2006; Ferguson and Warner, 2008; Abhijith et al., 2017; Gagaoua et al., 2017). DJ1 has previously been identified as being involved in quality grade (Thornton et al., 2017) and carcass growth (Picard et al., 2017) but is not known to be related to any other carcass characteristics.

Although a number of previous studies have identified a relationship between HSP and DJ1 abundance and various aspects of meat quality, the relationship between abundance of these anti-apoptotic proteins, carcass characteristics, and meat quality is not completely understood. Additionally, much of the research that has been presented on this topic provides contradictory results, warranting additional research to fully elucidate the relationship between abundance of HSP and DJ1, carcass characteristics, and meat quality. Therefore, the objective of this study was to evaluate the relationship of abundance of HSP and DJ1 with tenderness and meat quality of samples collected from the longissimus thoracis (LT) both pre-rigor and after $14 \mathrm{~d}$ of aging.

\section{Materials and Methods}

\section{Sample collection and preparation}

Samples were obtained from the LT of 99 randomly selected cattle finished in the Intermountain West at the same feedlot operation and harvested on 4 separate days at a commercial harvest facility (Hyrum, UT) following USDA guidelines. All cattle were Bos taurus mixed breed cattle between 16 and 20 mo of age and were raised using similar production practices for the area. Within $20 \mathrm{~min}$ of exsanguination $(0 \mathrm{~d})$, skeletal muscle samples were collected from the left LT pre-rigor. Samples were collected following previously described procedures (Thornton et al., 2017). In brief, a homemade core drilling device was used to collect skeletal muscle samples from between the 11th and 12th ribs. Samples were immediately snap frozen in liquid nitrogen and stored at $-80^{\circ} \mathrm{C}$ until further analysis. The left strip loin (Institutional Meat Purchase Specifications \#180) from each animal was obtained during fabrication approximately $24 \mathrm{~h}$ after exsanguination and transported to the Utah State University Meats Laboratory (Logan, UT), where it 
was then wet aged for $14 \mathrm{~d}$ at $4^{\circ} \mathrm{C}$. After the14-d aging period, a sample that was approximately $2 \mathrm{~g}$ in size was cut from the same LT when steaks were fabricated. Each sample was collected from the center of the fourth steak that was fabricated taking care to avoid connective tissues and intramuscular fat depots. This sample was snap frozen in liquid nitrogen and stored at $-80^{\circ} \mathrm{C}$ until further analysis was performed.

\section{Carcass characteristics}

At harvest, carcass characteristics were obtained from the commercial harvest facility. The carcass characteristics obtained were hot carcass weight, ribeye area (REA), marbling score, quality grade, and yield grade. Marbling score, quality grade, yield grade, and REA were all obtained from camera data provided by the commercial harvest facility.

\section{Western blotting}

Western blot analysis was used to detect abundance of HSP $\beta 1$, HSPA, and DJ1 in samples collected at both 0 $\mathrm{d}$ and $14 \mathrm{~d}$ of age. All samples collected from the LT were ground under liquid nitrogen using a mortar and pestle. Total protein was extracted following previously described methods (Thornton et al., 2017). In brief, between 50 and $70 \mathrm{mg}$ of ground tissue was transferred to $15 \mu \mathrm{L} / \mathrm{mg}$ tissue total protein extraction bu er $(50 \mathrm{mM}$ Tris- $\mathrm{HCl}$ [pH 7.52], $150 \mathrm{mM} \mathrm{NaCl}, 1 \mathrm{mM}$ ethylenediaminetetraacetic acid, $1 \%$ Tergitol, $0.1 \%$ sodium dodecyl sulfate [SDS], and $0.5 \%$ sodium deoxycholate). Immediately before use, phosphatase and protease inhibitor cocktail tablets (Roche, Indianapolis, IN) were added to the extraction bu er. Samples were homogenized and placed on a rocking platform for $10 \mathrm{~min}$ at $4^{\circ} \mathrm{C}$. All samples were centrifuged at $10,000 \times g$ for $10 \mathrm{~min}$ at $4^{\circ} \mathrm{C}$. The supernatant was removed and stored at $-80^{\circ} \mathrm{C}$. Samples were then quantified using a Pierce BCA Protein Assay Kit (ThermoFisher Scientific, Pittsburgh, PA) as per the manufacturer's protocol. Samples were diluted to a concentration of $10 \mu \mathrm{g} / \mu \mathrm{L}$ using extraction buffer, and $30 \mu \mathrm{L}$ of sample was loaded into each well of the gel. Eight individual samples were run on each gel for each protein analyzed; the same internal standard sample was also run on each gel for each protein to serve as a control between the different gels that were run. A total of 25 different gels were run, and samples were randomly assigned to each gel. Protein samples were run on gels following previously described procedures (Thornton et al., 2017). In brief, electrophoresis was performed at $140 \mathrm{~V}$ for $90 \mathrm{~min}$ at $4^{\circ} \mathrm{C}$ on $10 \%$ polyacrylamide gels using a Bio-Rad
Mini PROTEAN tetra cell (Bio-Rad, Hercules, CA) box in running buffer containing $25 \mathrm{mM}$ Tris, 192 $\mathrm{mM}$ glycine, and $0.1 \%(\mathrm{w} / \mathrm{v})$ SDS. The proteins were then transferred to a polyvinylidene difluoride membrane (Bio-Rad) at $100 \mathrm{~V}$ for $90 \mathrm{~min}$ at $4^{\circ} \mathrm{C}$ in a transfer buffer consisting of $20 \%(\mathrm{w} / \mathrm{v})$ methanol, $25 \mathrm{mM}$ Tris, $192 \mathrm{mM}$ glycine, and $0.05 \%(\mathrm{w} / \mathrm{v})$ SDS. Membranes containing the proteins were then blocked in a $5 \%(\mathrm{w} /$ v) nonfat milk and Tris-buffered saline (TBS; 100 $\mathrm{mM}$ Tris-HCl, $0.13 \mathrm{M} \mathrm{NaCl}$, and $0.0027 \mathrm{M} \mathrm{KCl}$ ) solution for $2 \mathrm{~h}$ at room temperature. Membranes were then rinsed 2 times in TBS, and then incubated with primary antibodies (HSP $\beta 1$, dilution 1:500, product \#PA125494, ThermoFisher; HSPA, dilution 1:1,000, product \#4872S, Cell Signaling Technologies, Danvers, MA; and DJ1, 1:1,000 dilution, product \#ab18257, Abcam, Cambridge, MA) in 5\% nonfat milk-TBS solution overnight at $4^{\circ} \mathrm{C}$. Membranes were then briefly washed in TBS and incubated in an anti-rabbit secondary antibody (1:1,000 dilution, product \#7074S, Cell Signaling Technologies) for $2 \mathrm{~h}$ at room temperature. Blots were then briefly washed in TBS and then placed in Western Sure Premium Chemiluminescent Substrate (LI-COR, Lincoln, NE) and imaged using a C-DiGit Blot Scanner (LI-COR). The band intensity of each band was quantified using Image Studio software (LI-COR). The density of the internal standard on each gel for each protein analyzed was used to standardize between different gels by adjusting the value of each sample relative to the internal standard.

\section{Preparation of steaks for meat quality analyses}

The same loin used for the previous sample collection (the left strip loin of each carcass) was also used for meat quality analysis. Strip loins were vacuum packaged and allowed to wet age for $14 \mathrm{~d}$ postmortem at refrigeration temperatures $\left(4^{\circ} \mathrm{C}\right)$. After the aging period, loins were frozen whole at $-20^{\circ} \mathrm{C}$ and stored prior to being fabricated into steaks. Frozen subprimal loins were cut using a band-saw (Butcher Boy; Model \#SA-16; American Meat Equipment, LLC, Selmer, TN) into 2.5-cm-thick steaks that were then placed into individual vacuum packaging and stored at $-20^{\circ} \mathrm{C}$ until further analyses were completed. Six consecutively cut steaks from each loin were used for meat quality testing: 1 for shear force, 2 for sensory, and 3 were retained for future needs. The first steak cut was always used for shear force, and the second 2 were always used for sensory to ensure that differences in steak location were not introducing bias into the analysis. Live animal ear tag 
number, carcass number, and loin number and steak number identification were used to link and identify individual animal to individual steak at each stage of meat production.

Cooking procedures for sensory and WarnerBratzler shear force (WBSF) analysis are described as follows. Steaks were allowed to thaw for $24 \mathrm{~h}$ at $4{ }^{\circ} \mathrm{C}$ in vacuum packaging. Steaks were trimmed to leave only the LT muscle. Prior to being placed on the grill, an initial internal temperature was recorded for each sample using a thermometer (IPX waterproof thermocouple; 352 Aqua Tuff; Cooper-Atkins, Middlefield, CT). Steaks were placed on a clam shell grill (Griddler Deluxe; Cuisinart; GR-150; East Windsor, $\mathrm{NJ})$ at a grill surface temperature of $232^{\circ} \mathrm{C}$ and cooked to a medium degree of doneness (internal temperature of $70^{\circ} \mathrm{C}$ ) monitored by an internal thermometer (IPX waterproof thermocouple; Cooper-Atkins).

\section{WBSF}

WBSF values were collected from 14-d-aged loin samples $(N=99)$ using methods outlined by the American Meat Science Association (American Meat
Science Association, 2015). Steak preparation and cooking was completed following the methods outlined earlier. After cooking, steaks were covered with plastic wrap on metal trays and allowed to rest $24 \mathrm{~h}$ at $4^{\circ} \mathrm{C}$. Steaks were then allowed to reach $23^{\circ} \mathrm{C}$ for a minimum of $1 \mathrm{~h}$ before being cored. Seven $1.27 \mathrm{~cm}$ core samples were taken from each steak sample following the grain of the longitudinal muscle fibers to be sheared on a TMS-Pro Texture Analyzer (FTC 500N ILC, Food Technology Corporation, Sterling, VA) with a specific blade attachment for WBSF using a $200 \mathrm{~mm} / \mathrm{min}$ crosshead speed and a $500 \mathrm{~kg}$ load cell.

\section{Sensory analysis}

For sensory analysis, steaks were cooked as described earlier, and sample preparation followed guidelines developed by the American Meat Science Association (2015). Following cooking, steaks were allowed to rest for $3 \mathrm{~min}$ before being cut into one $2 \times 2 \mathrm{~cm}$ and three $1 \times 1 \mathrm{~cm}$ samples and placed in a plastic sample cup with a plastic lid. The $2 \times 2 \mathrm{~cm}$ samples were used to evaluate tenderness and juiciness, while the $1 \times 1 \mathrm{~cm}$ samples were used for evaluation

Table 1. Sensory aroma and flavor references and definitions on a 1- to 15-point numerical scale with 0.5 increments and references associated with each attribute that were used to train the panel

\begin{tabular}{|c|c|c|}
\hline Attribute & Definition & Reference associated with attribute \\
\hline Beef flavor* & Amount of beef flavor & $\begin{array}{l}\text { Swanson's (Campbell Soup Company, Camden, } \mathrm{NJ} \text { ) beef broth }= \\
6.0 \\
80 \% \text { lean ground beef }=7.0 \\
\text { Beef brisket }=11.0\end{array}$ \\
\hline $\begin{array}{l}\text { Bloody/ } \\
\text { serumy* }\end{array}$ & $\begin{array}{l}\text { Aromatics of blood on cooked meat products, closely } \\
\text { related to metallic aromatic. }\end{array}$ & $\begin{array}{l}\text { USDA Choice strip steak }=5.5 \\
\text { Beef brisket }=6.0\end{array}$ \\
\hline $\begin{array}{l}\text { Brown/ } \\
\text { roasted* }\end{array}$ & Full aromatic generally associated with broiled beef suet & $\begin{array}{l}\text { Beef suet }=8.5 \\
80 \% \text { lean ground beef }=10.0\end{array}$ \\
\hline Fat-like* & Aromatics associated with cooked animal fat & $\begin{array}{l}\text { Hillshire Farms Lit'l Beef Smokies (Hillshire Farms, Chicago, } \\
\text { IL) }=7.0 \\
\text { Beef suet }=12.0\end{array}$ \\
\hline Liver-like & Aromatics associated with cooked organ meat/liver & $\begin{array}{l}\text { Flat iron steak }=3.0 \\
\text { Beef liver }=13.0\end{array}$ \\
\hline Oxidation & Aromatics associated with aged oil and fat & Beef suet $=2.0$ \\
\hline Bitter* & Taste factor associated with caffeine solution & $\begin{array}{l}0.01 \% \text { caffeine solution }=2.0 \\
0.02 \% \text { caffeine solution }=3.5\end{array}$ \\
\hline Salty* & Taste factor associated with sodium chloride solution & $\begin{array}{l}0.15 \% \text { sodium } \text { chloride solution }=1.5 \\
0.25 \% \text { sodium chloride solution }=3.5\end{array}$ \\
\hline Sour* & Taste factor associated with citric acid solution & $\begin{array}{l}0.015 \% \text { citric acid solution }=1.5 \\
0.050 \% \text { citric acid solution }=3.5\end{array}$ \\
\hline Umami* & $\begin{array}{l}\text { Flat, salty, brothy; taste of glutamate, salts of amino acids and } \\
\text { nucleotides }\end{array}$ & Swanson's beef broth $=4.5$ \\
\hline Tenderness & \multicolumn{2}{|c|}{ Ease with which sample can be cut through with molars after $3-4$ chews } \\
\hline Juiciness & \multicolumn{2}{|c|}{$\begin{array}{l}\text { Amount of juice released during the first } 3-4 \text { chews or the amount of moisture removed from the mouth during the first } 3-4 \text { chews } \\
\text { (dryness) }\end{array}$} \\
\hline
\end{tabular}

*Major attributes: attributes present in $99 \%$ of beef samples evaluated by Adhikari et al. (2011) sensory panel. 
of beef flavor attributes. Samples were placed on a warm clay brick (preheated in an oven at approximately $121^{\circ}$ C) to maintain sample temperature during evaluation. Samples were evaluated under red lighting. Distilled water and unsalted crackers were used as palette cleansers between each sample. Sensory evaluation was conducted at the Utah State University Department of Nutrition, Dietetics, and Food Science facilities by a trained flavor and texture descriptive panel $(n=8)$ with 12 beef lexicon attributes on a 16-point numerical scale with 0.5 increments (Adhikari et al., 2011). The panelists had over 3 y of experience in sensory evaluation of beef quality attributes. Fifteen training sessions were conducted using a series of steaks ranging in tenderness, juiciness, and beef flavor. Panelists' training used reference anchors outlined by the beef flavor and texture lexicon using previously described methods (Adhikari et al., 2011) to give a 0 to 15 numerical value of intensity for 12 beef sensory attributes, with 0 being slight, 7 the middle point, and 15 strong (Table 1). The panelists evaluated the steaks over a total of 10 different sessions.

\section{Myofibrillar fragmentation index}

Skeletal muscle from samples aged for $14 \mathrm{~d}$ postmortem were ground under liquid nitrogen, and myofibril fragments were extracted using previously described methods (Culler et al., 1978). In brief, ground tissue was submerged in myofibrillar fragmentation index (MFI) buffer $\left(100 \mathrm{mM} \mathrm{KCl}, 20 \mathrm{mM} \mathrm{KPO}_{4}^{-}\right.$ [pH 7], $1 \mathrm{mM}$ ethylene glycol-bis( $\beta$-aminoethyl ether)$\mathrm{N}, \mathrm{N}, \mathrm{N}^{\prime}, \mathrm{N}^{\prime}$-tetraacetic acid, $1 \mathrm{mM} \mathrm{MgCl}_{2}$, and $1 \mathrm{mM}$ $\mathrm{NaN}_{3}$ ). Tissue and MFI buffer were homogenized for $30 \mathrm{~s}$. Samples were centrifuged twice at $1,000 \times g$ for 15 min at $4^{\circ} \mathrm{C}$; supernatant was decanted, and $\mathrm{f}$ resh MFI buffer was added each time after samples were centrifuged. Myofibrillar fragments were then quantified using the Pierce BCA Protein Assay Kit (ThermoFisher Scientific). After quantification, samples were diluted to $500 \mu \mathrm{g} / \mathrm{mL}$, plated, and read at $540 \mathrm{~nm}$ on a BioTek Synergy H1 plate reader (BioTek, Winooski, VT). Myofibrillar fragmentation index was calculated using previously described methods (Culler et al., 1978).

\section{Statistical analysis}

The mean, minimum value, maximum value, and standard deviation of WBSF, MFI, carcass characteristics and sensory data of all samples can be seen in Table 2. All analyses were completed using the PROC MIXED procedure of SAS version 9.4 (SAS Institute Inc., Cary, NC). The protein abundance values were continuous independent variables, and the blot and kill date were treated as random effects. Residuals from this analysis, which are the protein abundance values adjusted for the effects of blot and kill date, were then used as continuous independent variables. The sensory data for each steak were collected from each of the 8 different panelists, and the average of the scores determined by each panelist for each trait were used in the statistical analysis. The sensory-related and carcass characteristics data were analyzed using stepwise linear regression implemented by backward elimination. The sensoryrelated attributes of the meat and carcass characteristics were the independent variables. Upon obtaining a final model for each trait or characteristic, containing kill date and all continuous effects that were deemed important $(P \leq 0.10)$, the least-squares means for each sensoryrelated attribute were predicted at the 25 th and 75 th percentiles of the distribution of any continuous variables remaining in the model. Correlations were determined using Pearson correlations. $P<0.05$ was considered statistically significant, whereas $P<0.10$ was considered a trend in the data. All data are presented as the leastsquares mean $\pm \mathrm{SEM}$.

\section{Results}

The mean, minimum value, maximum value, and standard deviation of the carcass characteristics, loin weights, flavor attributes, and tenderness measurements can be found in Table 2 .

\section{Carcass characteristics and loin weights}

Protein abundance of HSPA, HSP $\beta 1$, or DJ1 in samples collected at day 0 or day 14 was not associated $(P>0.10)$ with any of the measured carcass characteristics or loin weights (data not shown).

\section{Tenderness}

Abundance of HSPA in samples taken at day 0 or after $14 \mathrm{~d}$ of aging was not associated $(P>0.10)$ with tenderness as assessed by WBSF or MFI or with tenderness as determined by a sensory panel (data not shown). Furthermore, abundance of HSP $\beta 1$ or DJ1 in samples collected on day 0 was not associated $(P$ $>0.10$ ) with WBSF, MFI, or sensory panel tenderness. In samples collected after $14 \mathrm{~d}$ of aging, abundance of DJ1 was found to be a predictor of WBSF $(P<0.001)$, MFI $(P=0.02)$, and sensory panel tenderness $(P<$ 0.001) (Table 3). Additionally, abundance of HSP $\beta 1$ after $14 \mathrm{~d}$ of aging was found to be a predictor of 
Table 2. Overview of tenderness and sensory attributes of longissimus thoracis samples utilized in the present study

\begin{tabular}{|c|c|c|c|c|}
\hline Trait & Mean & Minimum value & Maximum value & Standard deviation \\
\hline Hot carcass weight, kg & 425.1 & 303.6 & 508.6 & 39.2 \\
\hline Loin weight, $\mathrm{kg}$ & 7.52 & 5.64 & 9.32 & 0.78 \\
\hline Backfat thickness, cm & 1.12 & 0.20 & 2.24 & 0.40 \\
\hline Ribeye area, $\mathbf{c m}^{2}$ & 94.3 & 75.5 & 115.5 & 7.9 \\
\hline Marbling score & 392.1 & 304.0 & 575.0 & 69.2 \\
\hline Yield grade & 2.82 & 1.5 & 5.0 & 0.67 \\
\hline WBSF, $\mathbf{N}$ & 35.1 & 19.4 & 54.8 & 6.9 \\
\hline MFI $^{1}$ & 42.5 & 7.5 & 153.5 & 29.3 \\
\hline Beef flavor ${ }^{2}$ & 7.29 & 2.19 & 8.10 & 0.64 \\
\hline Bloody/serumy ${ }^{2}$ & 3.36 & 1.17 & 5.00 & 0.65 \\
\hline Brown/roasted ${ }^{2}$ & 6.42 & 4.83 & 8.71 & 0.78 \\
\hline Fat like $^{2}$ & 2.17 & 1.10 & 3.75 & 0.54 \\
\hline Liver like $^{2}$ & 0.52 & 0.00 & 1.57 & 0.38 \\
\hline Oxidized $^{2}$ & 0.69 & 0.00 & 2.00 & 0.40 \\
\hline Sour $^{2}$ & 0.85 & 0.36 & 1.75 & 0.28 \\
\hline Bitter $^{2}$ & 0.53 & 0.00 & 1.07 & 0.21 \\
\hline Salty $^{2}$ & 1.15 & 0.58 & 1.88 & 0.29 \\
\hline Umami $^{2}$ & 2.92 & 1.50 & 4.36 & 0.51 \\
\hline Tenderness $^{2}$ & 7.63 & 1.76 & 10.38 & 1.14 \\
\hline Juiciness $^{2}$ & 7.40 & 1.76 & 9.33 & 1.03 \\
\hline
\end{tabular}

${ }^{1}$ MFI was calculated as described by Culler et al (1978).

${ }^{2}$ These values were determined by a trained taste panel as described in Table 1.

MFI, myofibrillar fragmentation index; WBSF, Warner-Bratzler shear force.

Table 3. Effects of high and low levels of abundance of DJ1 or HSP $\beta 1$ after 14-d aging on WBSF, MFI, or sensory panel tenderness in the longissimus thoracis

\begin{tabular}{|c|c|c|c|c|}
\hline \multirow[b]{2}{*}{ Trait } & \multicolumn{2}{|c|}{ Abundance level } & \multirow[b]{2}{*}{ Difference $^{1}$} & \multirow[b]{2}{*}{ Probability $^{2}$} \\
\hline & $\operatorname{High}^{1}$ & Low $^{1}$ & & \\
\hline \multicolumn{5}{|l|}{$D J 1$} \\
\hline WBSF, N & $35.7 \pm 0.59$ & $33.54 \pm 0.59$ & $2.16 \pm 0.59$ & $<0.001$ \\
\hline $\mathrm{MFI}^{3}$ & $50.5 \pm 4.1$ & $39.2 \pm 4.3$ & $11.4 \pm 4.7$ & 0.02 \\
\hline Tenderness $^{3}$ & $7.48 \pm 0.12$ & $7.91 \pm 0.12$ & $-0.43 \pm 0.11$ & $<0.001$ \\
\hline \multicolumn{5}{|l|}{ HSP 1} \\
\hline $\mathrm{MFI}^{3}$ & $37.3 \pm 4.9$ & $51.0 \pm 4.4$ & $-13.7 \pm 6.2$ & 0.03 \\
\hline
\end{tabular}

${ }^{1}$ The tabled values are those predicted by the regression at the 25 th (low) and 75 th (high) percentiles of the distribution of protein abundance levels. Thus, they are nominally equivalent to least-squares means of the low and high groups had the data been divided in high and low classes. It is also important to note that each analysis was completed independently, and as such, the samples that are in the "low" and "high" groups are not the same for each protein or for each trait.

${ }^{2} \alpha=0.05$.

${ }^{3}$ Tenderness values are those determined by the trained taste panel as described in Table 1. MFI was calculated as described by Culler et al (1978).

DJ1, deglycase; HSP $\beta 1$, heat shock protein $\beta 1$; MFI, myofibrillar fragmentation index; WBSF, Warner-Bratzler shear force.

MFI $(P=0.03)$ but was not associated $(P>0.10)$ with WBSF or tenderness (Table 3 ).

\section{Flavor attributes}

Using regression analysis, abundance of DJ1 was found to be a predictor of juiciness $(P=0.04)$ and tended to predict umami $(P=0.06)$ in samples of beef collected pre-rigor (Table 4). However, abundance of DJ1 in samples collected on day 0 was not $(P>$ $0.10)$ a predictor of any of the other sensory attributes listed in Table 1 (data not shown). Furthermore, in samples collected after $14 \mathrm{~d}$ of aging, abundance of DJ1 
Table 4. Effects of high and low levels of abundance of DJ1, HSP $\beta 1$, or HSPA in samples collected pre-rigor on juiciness, umami, or fat-like flavor in the longissimus thoracis

\begin{tabular}{|c|c|c|c|c|}
\hline \multirow[b]{2}{*}{ Trait } & \multicolumn{2}{|c|}{ Abundance level } & \multirow[b]{2}{*}{ Difference $^{1}$} & \multirow[b]{2}{*}{ Probability $^{2}$} \\
\hline & $\operatorname{High}^{1}$ & Low $^{1}$ & & \\
\hline \multicolumn{5}{|l|}{$D J 1$} \\
\hline Juiciness $^{3}$ & $7.38 \pm 0.14$ & $7.73 \pm 0.14$ & $-0.35 \pm 0.16$ & 0.04 \\
\hline Umami $^{3}$ & $2.84 \pm 0.06$ & $2.99 \pm 0.06$ & $-0.14 \pm 0.08$ & 0.06 \\
\hline \multicolumn{5}{|l|}{$H S P \beta 1$} \\
\hline Juiciness $^{3}$ & $3.63 \pm 4.9$ & $3.37 \pm 4.4$ & $0.25 \pm 0.06$ & $<0.001$ \\
\hline \multicolumn{5}{|l|}{ HSPA } \\
\hline Juiciness $^{3}$ & $7.64 \pm 0.13$ & $7.45 \pm 0.12$ & $0.19 \pm 0.11$ & 0.09 \\
\hline Fat-like flavor ${ }^{3}$ & $2.27 \pm 0.07$ & $2.19 \pm 0.07$ & $0.08 \pm 0.05$ & 0.07 \\
\hline
\end{tabular}

${ }^{1}$ The tabled values are those predicted by the regression at the 25th (low) and 75th (high) percentiles of the distribution of protein abundance levels. Thus, they are nominally equivalent to least-squares means of the low and high groups had the data been divided in high and low classes. It is also important to note that each analysis was completed independently, and as such, the samples that are in the "low" and "high" groups are not the same for each protein or for each trait.

${ }^{2} \alpha=0.05$

${ }^{3}$ These values were determined by a trained taste panel as described in Table 1 .

DJ1, deglycase; HSPA, heat shock protein A; HSP $\beta 1$, heat shock protein $\beta 1$.

was not found to be predictive $(P>0.10)$ of any of the sensory attributes listed in Table 1 (data not shown). Abundance of HSP $\beta 1$ after $14 \mathrm{~d}$ of aging was also not found to be a predictor $(P>0.10)$ of any of the sensory attributes shown in Table 1 (data not shown). However, abundance of HSP $\beta 1$ in samples collected on day 0 was a predictor $(P=0.03)$ of juiciness (Table 4) but was not a predictor of any of the other sensory attributes shown in Table 1 (data not shown). Regression analysis also demonstrated that abundance of HSPA assessed after $14 \mathrm{~d}$ of aging was not a predictor $(P>0.10)$ of any of the sensory attributes shown in Table 1 (data not shown). However, abundance of HSPA in samples collected at day 0 was a predictor for both juiciness $(P=0.09)$ and fat-like flavor $(P=$ $0.07)$ but was not associated with any of the other sensory attributes listed in Table 1 (Table 4).

\section{Correlations between sensory attributes, WBSF, MFI, carcass characteristics, and protein abundance of HSPB1, HSPA, and DJ1}

The measured abundance of HSP $\beta 1$ in samples collected at day 0 and after $14 \mathrm{~d}$ of aging was positively correlated with WBSF $(P<0.001)$ (Figure 1). Additionally, abundance of DJ1 in samples collected at both time points was also positively correlated with WBSF $(P<0.001)$ (Figure 2). However, abundance of HSPA was not correlated with WBSF $(P>0.05)$ in samples collected at either time point (data not shown). Sensory analysis of beef flavor, umami, tenderness, and juiciness were each found to be negatively correlated $(P<0.05)$ with WBSF (Table 5). Furthermore, abundance of HSP $\beta 1$ and DJ1 at both $0 \mathrm{~d}$ and $14 \mathrm{~d}$ were
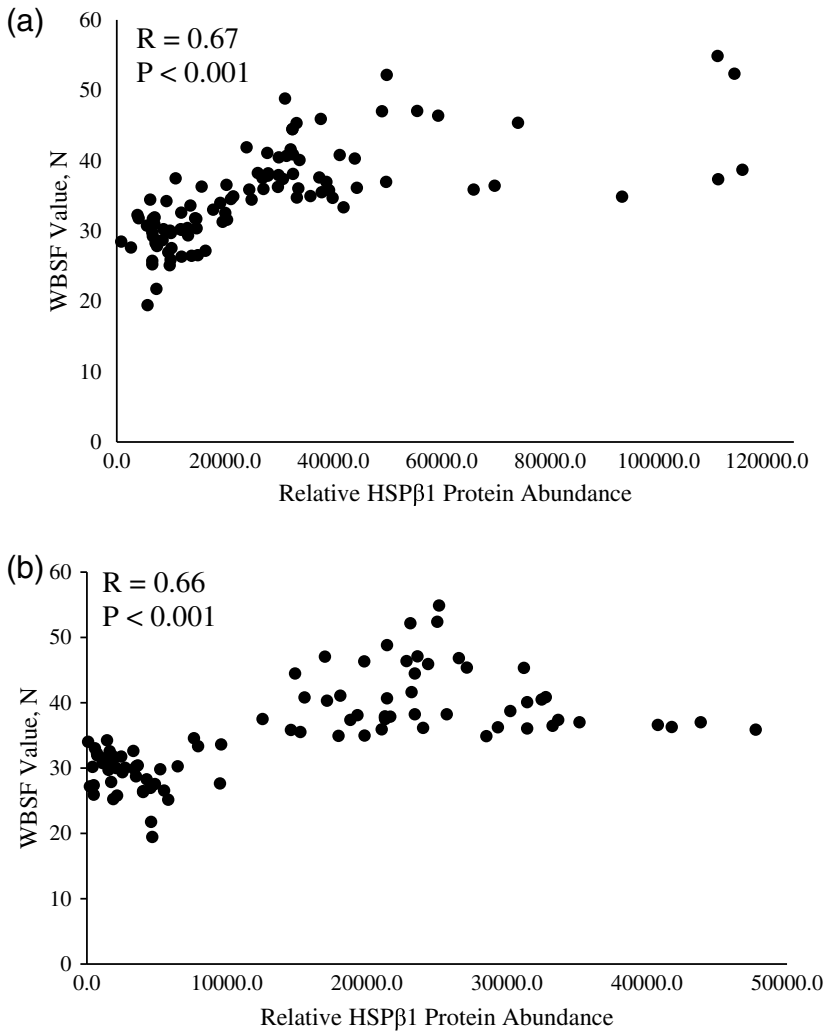

Figure 1. Correlation between protein abundance of heat shock protein beta 1 (HSP $\beta 1)$ and Warner-Bratzler shear force (WBSF) value $(N=99)$ of 14-d-aged steaks. Panel A describes the correlation in samples collected pre-rigor, and panel B describes the correlation in samples collected after $14 \mathrm{~d}$ of aging. Correlations were conducted using Spearman-Pearson correlations. 

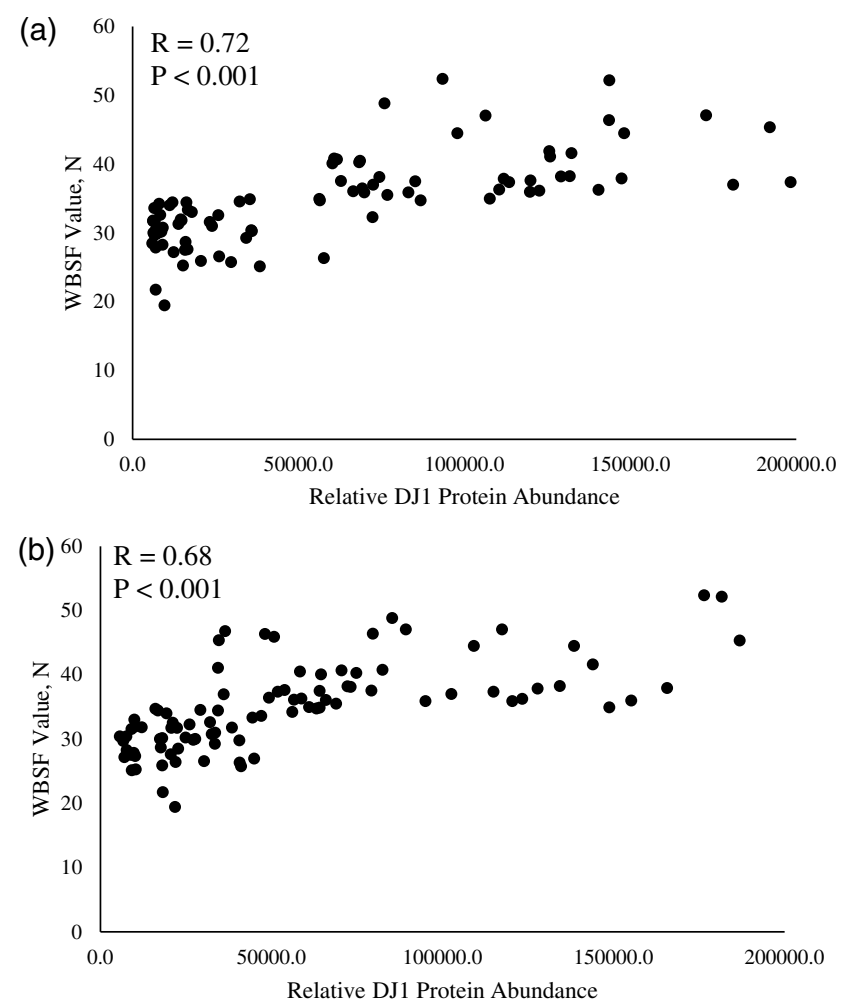

Figure 2. Correlation between protein abundance of a protein involved in oxidative stress (deglycase [DJ1]) and Warner-Bratzler shear force (WBSF) value $(N=99)$ of 14 -d-aged steaks. Panel A describes the correlation in samples collected pre-rigor, and panel B describes the correlation in samples collected after $14 \mathrm{~d}$ of aging. Correlations were conducted using Spearman-Pearson correlations. found to be negatively $(P<0.05)$ correlated with umami, tenderness, and juiciness (Table 5). Abundance of HSP $\beta 1$ at $14 \mathrm{~d}$ was also negatively $(P$ $<0.05)$ correlated with brown/roasted flavor (Table 5). In addition, WBSF was negatively $(P<$ $0.05)$ correlated with backfat thickness and marbling score and positively $(P<0.05)$ correlated with yield grade (Table 5). Abundance of HSP $\beta 1$ at day 0 or day 14 showed no $(P>0.05)$ correlation with any of the carcass characteristics (Table 5). However, abundance of HSPA collected at $0 \mathrm{~d}$ exhibited a negative $(P<0.05)$ correlation with loin weight (Table 5). Yield grade was also negatively $(P<0.05)$ correlated with DJ1 collected at $0 \mathrm{~d}$ (Table 5).

\section{Discussion}

Skeletal muscle becomes meat through metabolic changes that occur within muscle during the postmortem conversion to meat. Postmortem metabolism creates a situation in which myocytes, the cells that compose the skeletal muscle, undergo cellular stress. A number of physiological process are altered within the stressed myocytes, including a switch from aerobic to anaerobic metabolism, a drop in $\mathrm{pH}$, temperature fluctuations, and an increase in proteolytic enzymes

Table 5. Correlation between protein abundance, sensory values, and MFI

\begin{tabular}{|c|c|c|c|c|c|c|c|}
\hline & WBSF $^{1}$ & $\mathrm{HSP} \beta 10 \mathrm{~d}^{1}$ & $\mathrm{HS} \beta 114 \mathrm{~d}^{1}$ & DJ1 $0 \mathrm{~d}^{1}$ & DJ1 $14 \mathrm{~d}^{1}$ & HSPA $0 \mathrm{~d}^{1}$ & HSPA $14 \mathrm{~d}^{1}$ \\
\hline Beef flavor ${ }^{2}$ & $-0.21 *$ & -0.15 & -0.17 & -0.1 & -0.15 & -0.03 & 0.004 \\
\hline Bloody/serumy ${ }^{2}$ & -0.09 & -0.17 & -0.14 & -0.09 & -0.01 & 0.11 & 0.24 \\
\hline Brown/roasted $^{2}$ & -0.17 & -0.13 & $-0.3 *$ & -0.17 & -0.13 & -0.04 & -0.13 \\
\hline Fat like $^{2}$ & -0.02 & -0.11 & -0.14 & 0.09 & 0.09 & 0.06 & -0.04 \\
\hline Liver like $^{2}$ & -0.11 & 0.04 & 0.1 & 0.02 & -0.09 & -0.11 & -0.02 \\
\hline Oxidized $^{2}$ & 0.08 & 0.1 & 0.12 & 0.03 & 0.11 & 0.02 & -0.15 \\
\hline Sour $^{2}$ & -0.01 & -0.04 & 0.15 & 0.07 & 0.07 & 0.12 & 0.11 \\
\hline Bitter $^{2}$ & 0.05 & 0.03 & 0.11 & 0.08 & 0.09 & 0.08 & 0.07 \\
\hline Salty $^{2}$ & -0.18 & -0.06 & -0.17 & -0.04 & -0.08 & 0.04 & -0.01 \\
\hline Umami $^{2}$ & $-0.3^{*}$ & $-0.2 *$ & $-0.33^{*}$ & $-0.31^{*}$ & $-0.28 *$ & -0.003 & 0.06 \\
\hline Tenderness $^{2}$ & $-0.55^{*}$ & $-0.44 *$ & $-0.55^{*}$ & $-0.44 *$ & $-0.48^{*}$ & 0.02 & 0.08 \\
\hline Juiciness $^{2}$ & $-0.25^{*}$ & $-0.3^{*}$ & $-0.34 *$ & $-0.24 *$ & $-0.21^{*}$ & 0.10 & 0.06 \\
\hline MFI & -0.04 & 0.07 & -0.02 & 0.10 & 0.17 & -0.02 & -0.10 \\
\hline Hot carcass weight & -0.10 & -0.12 & -0.12 & -0.10 & -0.13 & -0.22 & 0.02 \\
\hline Loin weight & -0.02 & -0.10 & -0.006 & -0.008 & -0.08 & $-0.26^{*}$ & -0.02 \\
\hline Backfat thickness & $-0.21 *$ & -0.04 & -0.01 & -0.17 & -0.19 & -0.17 & -0.11 \\
\hline Ribeye area & 0.05 & 0.02 & -0.01 & 0.07 & -0.10 & -0.13 & -0.04 \\
\hline Marbling score & $-0.21 *$ & -0.05 & -0.10 & -0.13 & -0.06 & -0.16 & 0.07 \\
\hline Yield grade & $0.72 *$ & -0.12 & -0.06 & $-0.21 *$ & -0.15 & -0.15 & -0.04 \\
\hline
\end{tabular}

${ }^{1}$ Values represent the $R$ value between the variables found in corresponding rows and columns; values with a "*” indicate a correlation of $P \leq 0.05$.

${ }^{2}$ Sensory values obtained using a trained panel, based on a 15-point numerical scale outlined in Adhikari et al. (2011).

DJ1, deglycase; HSPA, heat shock protein A; HSP $\beta 1$, heat shock protein $\beta 1$; MFI, myofibrillar fragmentation index; WBSF, Warner-Bratzler shear force. 
(Morzel et al., 2008). The rate and extent of postmortem breakdown of myofibrillar proteins is a major determinant of end-product tenderness (Koohmaraie and Geesink, 2006; Laville et al., 2009). Several muscle endopeptidases, such as calpains and cathepsins, have a major role in the tenderizing process and have been studied at length, although questions remain as to what is responsible for the variability that still remains in these processes (Sentandreu et al., 2002; Pulford et al., 2008). Recent high-throughput analyses have determined that anti-apoptotic proteins, such as HSP and DJ1, may be contributing to variability in tenderness (Guillemin et al., 2011b; Hocquette et al., 2012b; Ma and Kim, 2020). As molecular chaperones, HSP assist with protein assembly, protein folding and unfolding, translocation, interacting with denatured proteins, and preventing protein aggregation to maintain cellular homeostasis and ultimately prevent apoptosis (Xing et al., 2018). After exsanguination, muscle cells become stressed as oxygen supply is depleted. HSP appear as soon as the cell is stressed, and contribute to proper conformation of proteins and preservation of their biological function (Herrera-Mendez et al., 2006). DJ1 is another protein that is thought to prevent cellular apoptosis (Laville et al., 2009; Longo et al., 2015). DJ1 is believed to prevent cellular apoptosis by protecting the cell from oxidative damages (Meulener et al., 2005; McNally et al., 2011). The goal of this research was to determine the relationship between abundance of proteins known to protect the cell from apoptosis (HSPA, HSP $\beta 1$, and DJ1) and beef tenderness, sensory traits, and carcass characteristics in order to better understand the factors responsible for meat quality. The present study utilized both linear regression analyses - to determine whether abundance of the proteins of interest could be used to predict the measured meat quality traits - and carcass characteristics, as well as correlations, in order to more loosely determine whether there is a relationship between the proteins of interest and meat quality and carcass characteristics.

The present study evaluated the relationship between carcass characteristics and protein abundance of HSP $\beta 1$, HSPA, and DJ1. Breeds of cattle that have a more excitable temperament, such as Bos indicus cattle, are more susceptible to stress and often produce a lower-quality carcass compared with Bos taurus bred cattle (Crouse et al., 1989; Shackelford et al., 1995; Voisinet et al., 1997; Petherick et al., 2002). Recent research has demonstrated that Bos indicus cattle have increased abundance of HSPA and HSP $\beta 1$ in skeletal muscle compared with Bos taurus cattle (Adamowicz et al., 2005; Lamb et al., 2007; Mullins et al., 2016). As such, the authors of the present study hypothesized that abundance of HSPA, HSP $\beta 1$, and DJ1 would have a negative relationship with desirable carcass characteristics (lower yield grade, increased marbling score, decreased "waste" fat, and increased REA). However, in the present study, regression analyses demonstrated that abundance of neither HSPA, HSP $\beta 1$, nor DJ1 measured at either time point was a predictor of any of the measured carcass characteristics. Additionally, abundance of HSP $\beta 1$ at either time point showed no correlation with any of the carcass characteristics. HSPA collected pre-rigor was negatively correlated with loin weight, and DJ1 at $0 \mathrm{~d}$ was negatively correlated with yield grade; although significant, the $R^{2}$ values demonstrate that less than $10 \%$ of the variability in these traits is explained by abundance of these proteins. Previous research indicates that steers with increased yield grade exhibit decreased expression of HSP $\beta 1$ (Keady et al., 2013). Abundance of DJ1 was also previously found to be related with carcass growth (Picard et al., 2017) and quality grade (Thornton et al., 2017). To date, very little research assessing the relationship of HSPA, HSP $\beta 1$, and DJ1 with carcass characteristics has been completed. Although the present study found little relationship between abundance of these proteins and carcass characteristics, more research needs to be done to further assess whether these relationships exist in different scenarios, such as when a larger number of animals is assessed, or whether differences exist between breeds.

Many previous studies have found that abundance of both genes and proteins involved in protecting cells from apoptosis, such as HSPA, HSP $\beta 1$, and DJ1, have a relationship with development of meat tenderness (Guillemin et al., 2011a; D’Alessandro et al., 2012b; Picard and Gagaoua, 2017; Rosa et al., 2017; Malheiros et al., 2018; Malheiros et al., 2019; Gagaoua et al., 2020; Ma and Kim, 2020). The tenderization process is driven by proteolysis of key myofibrillar proteins in conjunction with other factors such as the amount of lipid and connective tissue present (Koohmaraie, 1994; Koohmaraie et al., 2002; Bekhit et al., 2014; Lana and Zolla, 2016). As such, it has been hypothesized that the presence of proteins known to protect the cell from stress inhibit the proteolysis process, thus resulting in less tender meat (D'Alessandro et al., 2012b; Ouali et al., 2013; Picard and Gagaoua, 2017). HSPA is an HSP that is both constitutively expressed and upregulated in response to stress and is ATP dependent (Welch, 1992; Creagh et al., 2000). Because HSPA is ATP dependent, its role 
postmortem is not fully understood. HSP $\beta 1$ is a member of the small HSP family, is ATP independent, and is known to specifically protect several key myofibrillar proteins such as actin, troponin, and tropomyosin, which is why it is the most studied HSP in relationship to meat quality (Morzel et al., 2008; Mymrikov et al., 2011; Balan et al., 2014; Carvalho et al., 2014; Lomiwes et al., 2014; Cassar-Malek et al., 2015). DJ1 is another anti-apoptotic protein that is thought to inhibit the postmortem tenderization by inhibiting proteolysis (Laville et al., 2009; Longo et al., 2015). However, DJ1 prevents apoptosis by protecting the cell from oxidative damage (Meulener et al., 2005; McNally et al., 2011). In the present study, the authors hypothesized that decreased abundance of HSPA, HSP $\beta 1$, and DJ1 would be predictors of beef tenderness. In the present study, neither abundance of HSPA nor of HSP $\beta 1$ could be used to predict tenderness. However, our results demonstrate that abundance of HSP $\beta 1$ in the LT both pre-rigor and at $14 \mathrm{~d}$ of aging is correlated with tenderness. These 2 different analyses reveal that there is a relationship between tenderness and abundance of HSP $\beta 1$ but do not indicate that HSP $\beta 1$ is a causative factor in development of tenderness. Additionally, DJ1 protein abundance was found to predict tenderness. Taken together, these results indicate that abundance of both DJ1 and HSP $\beta 1$ are correlated with tenderness and DJ1 can be used to predict tenderness, whereas HSPA was not shown to have a relationship with tenderness.

Several previous studies have analyzed the relationship of HSPA, HSP $\beta 1$, and DJ1 with tenderness. An association between decreased tenderness and HSPA protein abundance in 2 different muscles of 3 French breeds of cattle was previously identified (Picard et al., 2014). Furthermore, a study utilizing Charolais bulls and steers observed a negative correlation between HSPA abundance and tenderness in the LT (Hocquette et al., 2012a). Similar to HSPA, increased HSP $\beta 1$ protein abundance in meat with decreased tenderness has been observed (Kim et al., 2008; Balan et al., 2014). Studies involving a mice strain devoid of HSP $\beta 1$ saw higher myofibril denaturation, and higher intermyofibrillar space, than control mice in postmortem muscle (Cassar-Malek et al., 2015; Picard et al., 2016). In a group of Nellore bulls, researchers observed downregulation of HSP $\beta 1$ in moderately tender meat compared with very tough meat from the LT (Malheiros et al., 2018). Research involving Italian Simmental bulls showed that a positive correlation existed between HSP $\beta 1$ and shear force values. In addition, lower HSP $\beta 1$ protein abundance was observed in the LL when compared with the infraspinatus (Saccà et al., 2015). Furthermore, a previous study associated increased tenderness with DJ1 abundance using principal components analysis in 2 muscles across 3 breeds of cattle (Picard et al., 2013). In Holstein cattle between 29 and 90 mo of age, DJ1 was relatively high in abundance in the semimembranosus (SM) and had the lowest abundance in the semitendinosus (ST); however, the ST and the SM did not differ in tenderness (Ellies-Oury et al., 2019). Samples taken from the LT of Norwegian Red bulls had less DJ1 abundance in more tender samples using two-dimensional gel electrophoresis, but there was no difference in DJ1 abundance between tender and tough samples when analyzed via western blot (Jia et al., 2009). The results of the present study generally agree with the aforementioned studies in that increased abundance of HSPA, HSP $\beta 1$, and DJ1 was observed in less tender samples. However, a number of other studies have reported results that conflict with the findings of the present study as well as previously completed studies. HSPA abundance was found to be positively correlated with tenderness in the LT of Charolais bulls (Gagaoua et al., 2018). Similarly, in Norwegian Red heifers and steers, HSPA abundance was positively correlated with tenderness in the SM (Grabež et al., 2015). A recent study also reported no differences of HSP $\beta 1$ abundance in 12 different skeletal muscles from Aberdeen Angus steers of beef cattle (Temizkan et al., 2019). A positive relationship between tenderness and HSP $\beta 1$ in the LT and negative relationship in the ST has also been observed (Picard et al., 2014). Furthermore, previous research also indicates increased HSP $\beta 1$ in more tender samples from the LT in Nellore bulls and steers (Rosa et al., 2018). These conflicting results demonstrate that more research needs to be done to determine the role that HSPA, HSP $\beta 1$, and DJ1 may have in development of beef tenderness.

Although a number of studies have analyzed the relationship of HSPA, HSP $\beta 1$, and DJ1 with tenderness, few studies have analyzed whether there is a relationship between abundance of these protein and meat quality as assessed by a trained sensory panel. The results of the present study demonstrate that in samples collected pre-rigor, abundance of DJ1 is a predictor of juiciness and umami, abundance of HSP $\beta 1$ is a predictor of juiciness, and abundance of HSPA is a predictor of juiciness and fat-like flavor. Marbling score is one of the main factors known to impact juiciness (Platter et al., 2003; Thompson, 2004). Interestingly, there was no observed relationship between $\operatorname{HSP} \beta 1$, 
HSPA, or DJ1 and marbling score, despite the fact each of these proteins was found to predict juiciness. In another study, samples perceived as more tender, juicy, and flavorful by trained sensory panel had decreased abundance of HSP $\beta 1$ in the LT of Charolais bulls (Bernard et al., 2007). Increased abundance of DJ1 was also observed to be associated with decreased juiciness of ST and LT muscles samples in a study of Saler bulls (Picard et al., 2011). Few studies have evaluated the relationship between anti-apoptotic proteins and beef sensory traits. Results from the present study and others indicate that samples with less HSPA, HSP $\beta 1$, and DJ1 are more tender, juicy, and flavorful. Taken together, these results indicate that HSP and DJ1 may be potential biomarkers for beef tenderness; however, more research is needed to fully understand the relationship between abundance of HSP and DJ1 and beef sensory characteristics.

\section{Conclusions}

The results of this study demonstrate that abundance of HSPA, HSP $\beta 1$, and DJ1 have a relationship with both tenderness and meat quality as assessed by a trained sensory panel but do not exhibit any type of relationship with carcass characteristics. The measured abundance of DJ1 in the LT in samples collected after $14 \mathrm{~d}$ of aging was found to be a predictor of tenderness. Abundance of HSP $\beta 1$ showed a strong correlation with tenderness but was not found to be a predictor of tenderness when analyzed via linear regression. HSPA was not found to be a predictor of tenderness. In addition, in samples collected pre-rigor, abundance of DJ1 is a predictor of juiciness and umami, abundance of HSP $\beta 1$ is a predictor of juiciness, and abundance of HSPA is a predictor of juiciness and fat-like flavor. The results of the present study provide important insight into the relationship of abundance of HSPA, HSP $\beta 1$, and DJ1 with both meat quality and carcass characteristics. However, additional research is needed to provide more clarity about how these proteins are involved in the development of meat quality in order to produce higher-quality beef.

\section{Acknowledgments}

This research was supported by funds and meat samples provided by Simplot Land \& Livestock Co. The authors would like to acknowledge Dick Whittier for providing his time and equipment for sample collection of 14-d samples.

\section{Literature Cited}

Abhijith, A., A. Joy, P. Prathap, P. K. Vidya, P. A. A. Niyas, B. Madiajagan, G. Krishnan, A. Manimaran, B. Vakayil, K. Kurien, V. Sejian, and R. Bhatta. 2017. Role of heat shock proteins in livestock adaptation to heat stress. Journal of Dairy, Veterinary and Animal Research. 5:1-7. https://doi. org/10.15406/jdvar.2017.05.00127.

Adamowicz, T., E. Pers, and D. Lechniak. 2005. A new SNP in the $3^{\prime}$-UTR of the hsp 70-1 gene in Bos taurus and Bos indicus. Biochem. Genet. 43:623. https://doi.org/10.1007/s10528005-9119-2.

Adhikari, K., E. Chambers IV, R. Miller, L. Vázquez-Araújo, N. Bhumiratana, and C. Philip. 2011. Development of a lexicon for beef flavor in intact muscle. J. Sens. Stud. 26:413-420. https://doi.org/10.1111/j.1745-459X.2011.00356.x.

American Meat Science Association. 2015. Research guidelines for cookery, sensory evaluation, and instrumental tenderness measurements of meat. Version 1.0. Am. Meat Sci. Assoc., Champaign, Illinois.

Balan, P., Y. H. B. Kim, and R. Blijenburg. 2014. Small heat shock protein degradation could be an indicator of the extent of myofibrillar protein degradation. Meat Sci. 97:220-222. https:// doi.org/10.1016/j.meatsci.2014.01.019.

Baldassini, W. A., C. P. Braga, L. A. L. Chardulo, J. A. I. V. Silva, J. M. Malheiros, L. G. de Albuquerque, T. T. Fernandes, and P. de M. Padilha. 2015. Bioanalytical methods for the metalloproteomics study of bovine longissimus thoracis muscle tissue with different grades of meat tenderness in the Nellore breed (Bos indicus). Food Chem. 169:65-72. https://doi.org/ 10.1016/j.foodchem.2014.07.131.

Bekhit, A. A., D. L. Hopkins, G. Geesink, A. A. Bekhit, and P. Franks. 2014. Exogenous proteases for meat tenderization. Crit. Rev. Food Sci. 54:1012-1031. https://doi.org/10.1080/ 10408398.2011.623247.

Bernard, C., I. Cassar-Malek, M. Le Cunff, H. Dubroeucq, G. Renand, and J.-F. Hocquette. 2007. New indicators of beef sensory quality revealed by expression of specific genes. J. Agr. Food Chem. 55:5229-5237. https://doi.org/10.1021/ jf0633721.

Carvalho, M. E., G. Gasparin, M. D. Poleti, A. F. Rosa, J. C. C. Balieiro, C. A. Labate, R. T. Nassu, R. R. Tullio, L. C. de A. Regitano, G. B. Mourão, and L. L. Coutinho. 2014. Heat shock and structural proteins associated with meat tenderness in Nellore beef cattle, a Bos indicus breed. Meat Sci. 96:1318-1324. https://doi.org/10.1016/j.meatsci.2013. 11.014 .

Cassar-Malek, I., M. Kammoun, M. Astruc, C. Chambon, C. Barboiron, A. Delavaud, and B. Picard. 2015. An Hspb1-null mouse to depict the contribution of Hsp27 in beef tenderness. In: Proceedings of the 61th International Congress of Meat Science and Technology (ICoMST), Clermont-Ferrand, France. p. 23-28.

Creagh, E. M., D. Sheehan, and T. G. Cotter. 2000. Heat shock proteins-Modulators of apoptosis in tumour cells. Leukemia. 14:1161-1173. https://doi.org/10.1038/sj.leu.2401841.

Crouse, J. D., L. V. Cundiff, R. M. Koch, M. Koohmaraie, and S. C. Seideman. 1989. Comparisons of Bos indicus and Bos taurus inheritance for carcass beef characteristics and meat 
palatability. J. Anim. Sci. 67:2661-2668. https://doi.org/10. 2527/jas1989.67102661x.

Culler, R. D., F. C. Parrish, G. C. Smith, and H. R. Cross. 1978. Relationship of myofibril fragmentation index to certain chemical, physical and sensory characteristics of bovine longissimus muscle. J. Food Sci. 43:1177-1180. https://doi.org/ 10.1111/j.1365-2621.1978.tb15263.x.

D'Alessandro, A., C. Marrocco, S. Rinalducci, C. Mirasole, S. Failla, and L. Zolla. 2012a. Chianina beef tenderness investigated through integrated Omics. J. Proteomics. 75:43814398. https://doi.org/10.1016/j.jprot.2012.03.052.

D'Alessandro, A., S. Rinalducci, C. Marrocco, V. Zolla, F. Napolitano, and L. Zolla. 2012b. Love me tender: An Omics window on the bovine meat tenderness network. J. Proteomics. 75:4360-4380. https://doi.org/10.1016/j.jprot. 2012.02.013.

Ellies-Oury, M.-P., H. Lorenzo, C. Denoyelle, J. Saracco, and B. Picard. 2019. An original methodology for the selection of biomarkers of tenderness in five different muscles. Foods. 8:206. https://doi.org/10.3390/foods8060206.

Ferguson, D. M., and R. D. Warner. 2008. Have we underestimated the impact of pre-slaughter stress on meat quality in ruminants? Meat Sci. 80:12-19. https://doi.org/10.1016/j. meatsci.2008.05.004.

Gagaoua, M., M. Bonnet, M.-P. Ellies-Oury, L. De Koning, and B. Picard. 2018. Reverse phase protein arrays for the identification/validation of biomarkers of beef texture and their use for early classification of carcasses. Food Chem. 250:245-252. https://doi.org/10.1016/j.foodchem.2018. 01.070

Gagaoua, M., M. Bonnet, and B. Picard. 2020. Protein array-based approach to evaluate biomarkers of beef tenderness and marbling in cows: Understanding of the underlying mechanisms and prediction. Foods. 9:1180. https://doi.org/10.3390/ foods 9091180 .

Gagaoua, M., E. M. Claudia Terlouw, A. Boudjellal, and B. Picard. 2015. Coherent correlation networks among protein biomarkers of beef tenderness: What they reveal. J. Proteomics. 128:365-374. https://doi.org/10.1016/j.jprot. 2015.08.022.

Gagaoua, M., V. Monteils, S. Couvreur, and B. Picard. 2017. Identification of biomarkers associated with the rearing practices, carcass characteristics, and beef quality: An integrative approach. J. Agr. Food Chem. 65:8264-8278. https://doi.org/ 10.1021/acs.jafc.7b03239.

Grabež, V., M. Kathri, V. Phung, K. M. Moe, E. Slinde, M. Skaugen, K. Saarem, and B. Egelandsdal. 2015. Protein expression and oxygen consumption rate of early postmortem mitochondria relate to meat tenderness. J. Anim. Sci. 93:1967-1979. https://doi.org/10.2527/jas.2014-8575.

Guillemin, N., M. Bonnet, C. Jurie, and B. Picard. 2011a. Functional analysis of beef tenderness. J. Proteomics. 75:352-365. https://doi.org/10.1016/j.jprot.2011.07.026.

Guillemin, N., C. Jurie, I. Cassar-Malek, J.-F. Hocquette, G. Renand, and B. Picard. 2011b. Variations in the abundance of 24 protein biomarkers of beef tenderness according to muscle and animal type. Animal. 5:885-894. https://doi. org/10.1017/S1751731110002612.
Herrera-Mendez, C. H., S. Becila, A. Boudjellal, and A. Ouali. 2006. Meat ageing: Reconsideration of the current concept. Trends Food Sci. Tech. 17:394-405. https://doi.org/10. 1016/j.tifs.2006.01.011.

Hocquette, J.-F., C. Bernard-Capel, V. Vidal, B. Jesson, H. Levéziel, G. Renand, and I. Cassar-Malek. 2012a. The GENOTEND chip: A new tool to analyse gene expression in muscles of beef cattle for beef quality prediction. BMC Vet. Res. 8:135. https://doi.org/10.1186/1746-6148-8-135.

Hocquette, J.-F., R. Botreau, B. Picard, A. Jacquet, D. W. Pethick, and N. D. Scollan. 2012b. Opportunities for predicting and manipulating beef quality. Meat Sci. 92:197-209. https:// doi.org/10.1016/j.meatsci.2012.04.007.

Jia, X., E. Veiseth-Kent, H. Grove, P. Kuziora, L. Aass, K. I. Hildrum, and K. Hollung. 2009. Peroxiredoxin-6-A potential protein marker for meat tenderness in bovine longissimus thoracis muscle. J. Anim. Sci. 87:2391-2399. https://doi.org/ 10.2527/jas.2009-1792.

Keady, S. M., D. A. Kenny, K. Ohlendieck, S. Doyle, M. G. Keane, and S. M. Waters. 2013. Proteomic profiling of bovine M. longissimus lumborum from Crossbred Aberdeen Angus and Belgian Blue sired steers varying in genetic merit for carcass weight. J. Anim. Sci. 91:654-665. https://doi.org/10. 2527/jas.2012-5850.

Kim, N. K., S. Cho, S. H. Lee, H. R. Park, C. S. Lee, Y. M. Cho, Y. H. Choy, D. Yoon, S. K. Im, and E. W. Park. 2008. Proteins in longissimus muscle of Korean native cattle and their relationship to meat quality. Meat Sci. 80:1068-1073. https://doi. org/10.1016/j.meatsci.2008.04.027.

King, D. A., C. E. Schuehle Pfeiffer, R. D. Randel, T. H. Welsh, R. A. Oliphint, B. E. Baird, K. O. Curley, R. C. Vann, D. S. Hale, and J. W. Savell. 2006. Influence of animal temperament and stress responsiveness on the carcass quality and beef tenderness of feedlot cattle. Meat Sci. 74:546-556. https://doi.org/10.1016/j.meatsci.2006.05.004.

Koohmaraie, M. 1994. Muscle proteinases and meat aging. Meat Sci. 36:93-104. https://doi.org/10.1016/0309-1740(94) 90036-1.

Koohmaraie, M., and G. H. Geesink. 2006. Contribution of postmortem muscle biochemistry to the delivery of consistent meat quality with particular focus on the calpain system. Meat Sci. 74:34-43. https://doi.org/10.1016/j.meatsci.2006. 04.025 .

Koohmaraie, M., M. P. Kent, S. D. Shackelford, E. Veiseth, and T. L. Wheeler. 2002. Meat tenderness and muscle growth: Is there any relationship? Meat Sci. 62:345-352. https://doi. org/10.1016/S0309-1740(02)00127-4.

Lamb, M., R. Okimoto, M. Brown, and C. RosenkransJr. 2007. Associations between cattle breed and heat shock protein 70 gene. Arkansas Agricultural Extension Research Service. 545:205-206.

Lana, A., and L. Zolla. 2016. Proteolysis in meat tenderization from the point of view of each single protein: A proteomic perspective. J. Proteomics. 147:85-97. https://doi.org/10.1016/j. jprot.2016.02.011.

Laville, E., T. Sayd, M. Morzel, S. Blinet, C. Chambon, J. Lepetit, G. Renand, and J. F. Hocquette. 2009. Proteome changes during meat aging in tough and tender beef suggest the importance of apoptosis and protein solubility for beef aging and 
tenderization. J. Agr. Food Chem. 57:10755-10764. https:// doi.org/10.1021/jf901949r.

Lomiwes, D., M. M. Farouk, E. Wiklund, and O. A. Young. 2014. Small heat shock proteins and their role in meat tenderness: A review. Meat Sci. 96:26-40. https://doi.org/10.1016/j. meatsci.2013.06.008.

Longo, V., A. Lana, M. T. Bottero, and L. Zolla. 2015. Apoptosis in muscle-to-meat aging process: The omic witness. J. Proteomics. 125:29-40. https://doi.org/10.1016/j.jprot.2015. 04.023.

Lucero-Borja, J., L. B. Pouzo, M. S. de la Torre, L. Langman, F. Carduza, P. M. Corva, F. J. Santini, and E. Pavan. 2014. Slaughter weight, sex and age effects on beef shear force and tenderness. Livest. Sci. 163:140-149. https://doi.org/10. 1016/j.livsci.2014.02.003.

Ma, D., and Y. H. B. Kim. 2020. Proteolytic changes of myofibrillar and small heat shock proteins in different bovine muscles during aging: Their relevance to tenderness and water-holding capacity. Meat Sci. 163:108090. https://doi.org/10.1016/j. meatsci.2020.108090.

Malheiros, J. M., C. P. Braga, R. A. Grove, F. A. Ribeiro, C. R. Calkins, J. Adamec, and L. A. L. Chardulo. 2019. Influence of oxidative damage to proteins on meat tenderness using a proteomics approach. Meat Sci. 148:64-71. https://doi.org/ 10.1016/j.meatsci.2018.08.016.

Malheiros, J. M., C. E. Enríquez-Valencia, B. O. da Silva Duran, T. G. de Paula, R. A. Curi, J. A. I. I. de Vasconcelos Silva, M. Dal-Pai-Silva, H. N. de Oliveira, and L. A. L. Chardulo. 2018. Association of CAST2, HSP90AA1, DNAJA1 and HSPB1 genes with meat tenderness in Nellore cattle. Meat Sci. 138:49-52. https://doi.org/10.1016/j.meatsci.2018.01.003.

McNally, R. S., B. K. Davis, C. M. Clements, M. A. AccavittiLoper, T. W. Mak, and J. P.-Y. Ting. 2011. DJ-1 Enhances cell survival through the binding of Cezanne, a negative regulator of NF-кB. J. Biol. Chem. 286:4098-4106. https://doi. org/10.1074/jbc.M110.147371.

Meulener, M., A. J. Whitworth, C. E. Armstrong-Gold, P. Rizzu, P. Heutink, P. D. Wes, L. J. Pallanck, and N. M. Bonini. 2005. Drosophila DJ-1 mutants are selectively sensitive to environmental toxins associated with Parkinson's Disease. Curr. Biol. 15:1572-1577. https://doi.org/10.1016/j.cub.2005.07.064.

Miller, M. F., M. A. Carr, C. B. Ramsey, K. L. Crockett, and L. C. Hoover. 2001. Consumer thresholds for establishing the value of beef tenderness. J. Anim. Sci. 79:3062. https://doi.org/10. 2527/2001.79123062x.

Morzel, M., C. Terlouw, C. Chambon, D. Micol, and B. Picard. 2008. Muscle proteome and meat eating qualities of Longissimus thoracis of "Blonde d'Aquitaine" young bulls: A central role of HSP27 isoforms. Meat Sci. 78:297-304. https://doi.org/10.1016/j.meatsci.2007.06.016.

Mullins, C. R., H. N. Zerby, L. A. Fitzpatrick, and A. J. Parker. 2016. Bos indicus cattle possess greater basal concentrations of HSP27, alpha B-crystallin, and HSP70 in skeletal muscle in vivo compared with Bos taurus cattle. J. Anim. Sci. 94:424429. https://doi.org/10.2527/jas.2015-9630.

Mymrikov, E. V., A. S. Seit-Nebi, and N. B. Gusev. 2011. Large potentials of small heat shock proteins. Physiol. Rev. 91:1123-1159. https://doi.org/10.1152/physrev.00023.2010.
Ouali, A., M. Gagaoua, Y. Boudida, S. Becila, A. Boudjellal, C. H. Herrera-Mendez, and M. A. Sentandreu. 2013. Biomarkers of meat tenderness: present knowledge and perspectives in regards to our current understanding of the mechanisms involved. Meat Sci. 95:854-870. https://doi.org/10.1016/j. meatsci.2013.05.010.

Petherick, J. C., R. Holroyd, V. J. Doogan, and B. Venus. 2002. Productivity, carcass and meat quality of lot-fed Bos indicus cross steers grouped according to temperament. Aust. J. Exp. Agr. 42:389-398. https://doi.org/10.1071/EA01084.

Picard, B., and M. Gagaoua. 2017. Proteomic investigations of beef tenderness. In: M. L. Colgrave, editor, Proteomics in food science. Academic Press. p. 177-197. http://www.sciencedirect. com/science/article/pii/B9780128040072000114.

Picard, B., M.-P. Ellies, M. Gagaoua, J. Sarraco, and M. Chavent. 2017. Biomarker abundance in two beef muscles depending on animal breeding practices and carcass characteristics. Genomics and Proteomics. 2:1013.

Picard, B., M. Gagaoua, M. Kammoun, C. Terlouw, J. F. Hocquette, and D. Micol. 2013. Biomarkers of beef tenderness in young bulls of three breeds. In: Proceedings of the 59th International Congress of Meat Science and Technology, The Netherlands: Elsevier, Amsterdam. p. 4.

Picard, B., M. Gagaoua, D. Micol, I. Cassar-Malek, J.-F. Hocquette, and C. E. M. Terlouw. 2014. Inverse relationships between biomarkers and beef tenderness according to contractile and metabolic properties of the muscle. J. Agr. Food Chem. 62:9808-9818. https://doi.org/10.1021/jf501528s.

Picard, B., C. Jurie, F. Garcia-Launay, K. Meteau, J. Agabriel, and D. Micol. 2011. Marqueurs des qualités sensorielles de la viande bovine en race Salers ("Markers of beef sensory qualities in Salers breed"). Small Ruminant Res. 18:181-184.

Picard, B., M. Kammoun, M. Gagaoua, C. Barboiron, B. Meunier, C. Chambon, and I. Cassar-Malek. 2016. Calcium homeostasis and muscle energy metabolism are modified in HspB1-null Mice. Proteomes. 4:17. https://doi.org/10.3390/ proteomes4020017.

Picard, B., B. Lebret, I. Cassar-Malek, L. Liaubet, C. Berri, E. Le Bihan-Duval, J. F. Hocquette, and G. Renand. 2015. Recent advances in omic technologies for meat quality management. Meat Sci. 109:18-26. https://doi.org/10.1016/j.meatsci.2015. 05.003 .

Platter, W. J., J. D. Tatum, K. E. Belk, P. L. Chapman, J. A. Scanga, and G. C. Smith. 2003. Relationships of consumer sensory ratings, marbling score, and shear force value to consumer acceptance of beef strip loin steaks. J. Anim. Sci. 81:2741-2750. https://doi.org/10.2527/2003.81112741x.

Pulford, D. J., S. Fraga Vazquez, D. F. Frost, E. Fraser-Smith, P. Dobbie, and K. Rosenvold. 2008. The intracellular distribution of small heat shock proteins in post-mortem beef is determined by ultimate $\mathrm{pH}$. Meat Sci. 79:623-630. https://doi.org/ 10.1016/j.meatsci.2007.10.027.

Ritossa, F. 1962. A new puffing pattern induced by temperature shock and DNP in drosophila. Experientia. 18:571-573. https://doi.org/10.1007/BF02172188.

Rosa, A., C. Moncau, E. Mattos, M. Poleti, J. Balieiro, and J. Eler. 2017. Influence of heat shock protein activity on the beef tenderness during aging. Meat Muscle Biol. 1:145-145. https:// doi.org/10.22175/rmc2017.138. 
Rosa, A. F., C. T. Moncau, M. D. Poleti, L. D. Fonseca, J. C. C. Balieiro, S. L. E. Silva, and J. P. Eler. 2018. Proteome changes of beef in Nellore cattle with different genotypes for tenderness. Meat Sci. 138:1-9. https://doi.org/10.1016/j.meatsci. 2017.12.006.

Saccà, E., M. Corazzin, N. Pizzutti, G. Lippe, and E. Piasentier. 2015. Early post mortem expression of genes related to tenderization in two Italian Simmental young bulls' skeletal muscles differing in contractile type. Anim. Sci. J. 86:992999. https://doi.org/10.1111/asj.12386.

Sentandreu, M. A., G. Coulis, and A. Ouali. 2002. Role of muscle endopeptidases and their inhibitors in meat tenderness. Trends Food Sci. Tech. 13:400-421. https://doi.org/10.1016/S09242244(02)00188-7.

Shackelford, S. D., T. L. Wheeler, and M. Koohmaraie. 1995. Relationship between shear force and trained sensory panel tenderness ratings of 10 major muscles from Bos indicus and Bos taurus cattle. J. Anim. Sci. 73:3333-3340. https:// doi.org/10.2527/1995.73113333x.

Temizkan, M. C., A. G. Bayraktaroglu, and T. Kahraman. 2019. Differential expression analysis of meat tenderness governing genes in different skeletal muscles of bovines. J. Sci. Food Agr. 99:3240-3245. https://doi.org/10.1002/jsfa.9434.

Thompson, J. M. 2004. The effects of marbling on flavour and juiciness scores of cooked beef, after adjusting to a constant tenderness. Aust. J. Exp. Agr. 44:645-652. https://doi.org/ 10.1071/ea02171.

Thornton, K. J., K. C. Chapalamadugu, E. M. Eldredge, and G. K. Murdoch. 2017. Analysis of Longissimus thoracis protein expression associated with variation in carcass quality grade and marbling of beef cattle raised in the Pacific Northwestern United States. J. Agr. Food Chem. 65:1434 1442. https://doi.org/10.1021/acs.jafc.6b02795.

Tissiéres, A., H. K. Mitchell, and U. M. Tracy. 1974. Protein synthesis in salivary glands of Drosophila melanogaster: Relation to chromosome puffs. J. Mol. Biol. 84:389-398. https://doi. org/10.1016/0022-2836(74)90447-1.

Voisinet, B. D., T. Grandin, S. F. O'Connor, J. D. Tatum, and M. J. Deesing. 1997. Bos indicus-cross feedlot cattle with excitable temperaments have tougher meat and a higher incidence of borderline dark cutters. Meat Sci. 46:367-377. https://doi. org/10.1016/S0309-1740(97)00031-4.

Welch, W. J. 1992. Mammalian stress response: cell physiology, structure/function of stress proteins, and implications for medicine and disease. Physiol. Rev. 72:1063-1081. https:// doi.org/10.1152/physrev.1992.72.4.1063.

Xing, T., F. Gao, R. Tume, G. H. Zhou, and X.-L. Xu. 2018. Stress effects on meat quality: A Mechanistic perspective. Compr. Rev. Food Sci. F. https://doi.org/10.1111/1541-4337.12417. 